
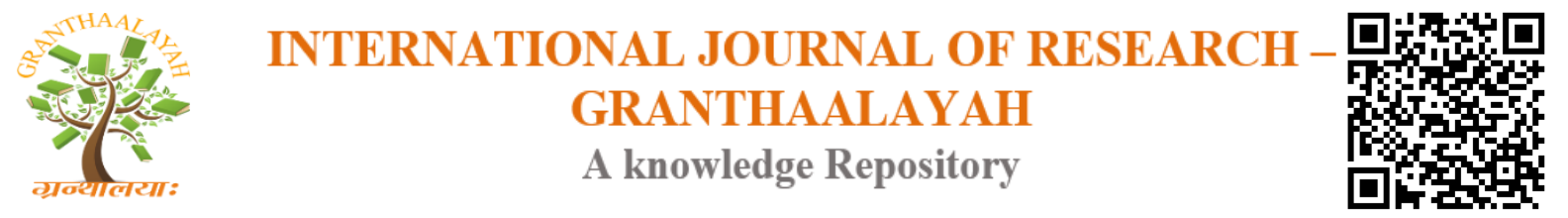

Management

\title{
RESEARCH AND EXTENSION PARTICIPATION, PERFORMANCE AND MOTIVATION OF THE LEYTE NORMAL UNIVERSITY FACULTY: INPUT TO POLICY REDIRECTION
}

\author{
Nestor C. Sedanza *1 \\ ${ }^{* 1}$ College of Management and Entrepreneurship, Leyte Normal University, Philippines
}

\begin{abstract}
Research and extension play vital roles in Higher Education Institutions (HEIs) in the Philippines being two of the four-fold functions of State Universities and Colleges (SUC). Hence, this study aimed to determine the research and extension participation, performance and motivation of the faculty members of Leyte Normal University as input to policy redirection. It utilized the descriptive research design and used purposive sampling to get the majority of the respondents. A survey questionnaire was used to obtain data from the respondents who were available during the conduct of the study. Findings of the study revealed that majority of the respondents got only satisfactory level of participation and performance in research and extension while most of them strongly agree on the statements on intrinsic and extrinsic motivations. Lack of time came out the number one problem encountered by the respondents in conducting research and extension programs, projects and activities. Also, majority of the respondents identified proper time from among the suggested solutions on problems encountered in the conduct of university's research and extension program, projects and activities.
\end{abstract}

Keywords: Research; Extension; Participation; Performance; Motivation; Level; Time; Faculty.

Cite This Article: Nestor C. Sedanza. (2018). "RESEARCH AND EXTENSION PARTICIPATION, PERFORMANCE AND MOTIVATION OF THE LEYTE NORMAL UNIVERSITY FACULTY: INPUT TO POLICY REDIRECTION." International Journal of Research - Granthaalayah, 6(11), 184-199. 10.29121/granthaalayah.v6.i11.2018.1117.

\section{Introduction}

The Leyte Normal University (LNU), a government institution of higher learning established under R.A. 7910 in 1995 (Revised LNU Code 2015), is mandated to perform the basic functions of higher education namely: instruction, research, extension and production.

Being a national mandate, it is obligatory for LNU to give the four functions equal attention. Hence, the Joint Circular No.1-A, s. 2016 amending the Joint Circular No.1-A, s. 2013 between the CHED, DBM and PASUC was issued to provide SUC levelling instrument and guidelines for implementation where the areas of instruction, research, extension, and management of resources 
will be evaluated in order to determine the University's level of performance for budgetary support and incentives. Also, for SUCs to catch up with top universities and colleges in other ASEAN countries (Revised CES Manual 2014).

LNU already has long established its research and extension culture via strategic and developmental plans. It has augmented those plans with research and extension agenda and manuals with implementing rules and regulations. It has research and extension organizational structures composed of vice president for research and extension, directors, college and program coordinators, faculty researchers and extensionists including students. Then, the research and extension councils which provides policy directions.

With regards to the workload for faculty with permanent and temporary status, the official time specifies the time spent for instruction (30 hours) but research and extension may be carried out anytime provided one completes 180 hours of research and another 180 hours of extension for one year which should be properly documented. Faculty with designations should also document research and extension involvement equivalent to 360 hours. Time spent for research and extension activities is supported by certificate of involvement with attached evidences such as SO's, certificate of attendance, certificate of service rendered, research papers, terminal reports, etc. A point-system provides an objective way of crediting research and extension involvement before a certificate is issued. The certificate of involvement is used as basis for determining faculty performance in research and extension. Awards and incentives are provided to deserving faculty members as a form of intrinsic motivation in conducting research and extension (Research and Extension Manuals).

In the last SUC levelling 2016 evaluation, LNU was only able to maintain its level III standing. Level $\mathrm{V}$ is the highest in terms of institutional performance. The key result areas (KRAs) that needs improvement in order for the University to reach the highest level are research and extension.

Universities in the Philippines must aspire to be not only institutions that provide instruction but institutions that are strong in research and extension. This is a challenge not only for Philippine universities but for universities in other countries as well (Aniga, 2011) (Villarino, 2012). This thrust is stressed in the World Conference on Higher Education Partners in June 2003 as UNESCO promoted policy dialogue that contribute to the enhancement of quality education, strengthening research capacities in higher education institutions, and knowledge sharing across borders (UNESCO, 2003)

Likewise, the Accrediting Agency of Chartered Colleges and Universities of the Philippines (AACCUP) Level IV-Phase 1 accreditation survey visit of Ed.D., MA and MAT programs of Leyte Normal University held on August 2016 resulted on more revisit areas to include research and extension. In addition, LNU were not able to receive the Performance Based Bonus (PBB) for 2015 up to the present because of failure to meet the minimum requirements in research.

The low performance of LNU on SUC levelling, AACCUP accreditation and PBB is quite alarming that administration has to do something to avert the situation. Hence, this study was conducted to find out the reasons behind this low productivity of faculty in research and extension programs, projects and activities in the University. 
This study was anchored on the Equity Theory developed by John Stacey Adams Daft in 2009 which proposes that people are motivated to seek social equity in the reward they expect for performance. According to this theory, if people perceive their compensation as equal to what others receive for similar contributions they will believe that treatment is fare and equitable. People evaluate equity by a ratio of inputs to outcomes.

Another theory that supports the study is by Moore \& Amey (2003) which believed that compensation system in an organization motivates behavior, recognizes and rewards employees' performance, and thus improves organizational effectiveness. As part of the compensation system, merit pay is at least theoretically, expected to reward outstanding performers. Lawler (2004) also believed that understanding motivation theory is critical to thinking analytically about all behavior in organizations and to make organization-design decisions.

Implicit in most motivation theories are intrinsic and extrinsic rewards. Intrinsic rewards may include a feeling of accomplishment and self-actualization while extrinsic rewards include benefits, recognition, status symbols, and money (Weihrich and Koontz, 2011) The abovementioned motivation theories if employed can affect the participation, performance and motivation of faculty in the conduct of University's research programs, projects and activities. Thus, this study was conducted to guide University policymakers in crafting effective-wise research and extension policies.

This study aimed to determine the research and extension participation, performance and motivation of the faculty of Leyte Normal University as input to policy redirection. Specifically, it sought to answer the following questions:

1) What is the profile of faculty in terms of:

- Sex

- Civil Status

- Educational Attainment

- Academic Rank

- Length of Academic Experience

- Designation

- Length of Designation Experience (yrs)

- No. of trainings/seminars/conferences attended related to research (last $3 \mathrm{yrs}$ )

- No. of trainings/seminars/conferences attended related to extension (last $3 \mathrm{yrs)}$

- Average teaching workload(hours/week) per semester

- No. of preparations per semester

2) What is the level of participation of faculty in research and extension?

3) What is the level of performance of faculty in research and extension?

4) What is the level of motivation faculty in research and extension?

5) What are the problems encountered by faculty in conducting research and extension services?

6) What are the suggested solutions to the problems encountered by faculty in conducting research and extension?

7) What policies and intervention program can be drawn out from this study? 
One way of measuring faculty productivity is teaching, generally quantified as courses taught and class size (Boyer, 2010). In a research university, however, faculty productivity is often assessed as scholarly publications and presentations, sometimes including grants (Braskamp, 2004)

A national movement has begun to broaden the definition of scholarship (Boyer, 2010) and to more comprehensively evaluate faculty members' contributions in the academe (Middaugh, 2010). However, in the research university, scholarly publications defined as peer-reviewed articles in recognized professional journals often function as the primary productivity measure in the granting of promotion and tenure (Wong \& Tierney, 2010).

Boyer (2010), Braskamp (2004), Middaugh (2010), Wong \& Tierney (2010) have similarity with the present study in relation to the faculty productivity in research, instruction and other extended activities; however there are some aspects that differs such as Boyer (2010) emphasized courses taught and class size; Brascamp (2004) that faculty productivity is often assessed as scholarly publications and presentations, sometimes including grants; Middaugh (2010) says that faculty members' contributions in the academy; and Wong \& Tierney (2010) recognized that professional journals is the productivity measure in the granting of promotion and tenure. This study investigated the faculty productivity both in research and extension functions.

Sy (2010) noted that participation in research related conferences, seminars, workshops, trainings, convocations, meetings within or outside the institution got the highest frequency in all SUCs. But such observation was in contrast with the findings of De Dios (2003) that teachers handling research instruction had inadequate training in research. But really, the institutions regularly provided trainings and seminars to improve the capability of the faculty in doing research. Likewise, Villarino (2015) revealed the perceptions of the faculty members as well as administrators on the research capability in terms of support facilities and conduct of research activities were of moderate extent and moderately agree, respectively; that the faculty members and administrators indicated as moderately felt problems related to research. Enriquez (2013) revealed her findings on the analysis of documents at the Research and Development Office (RDO) of Leyte Normal University for the last five years as follows: almost all of the faculty are capable of conducting research; capability building in research have been increasing; an increasing trend in researches conducted by faculty; increasing trend of researches presented by the faculty and students; increasing trend of researches published by the faculty; and low in externally funded researches. In contrast, Lacanaria's (2008) study on Faculty Research in Higher Education Institutions; Extent and Hindering Factors showed the following findings: limited researches conducted, disseminated, and published; minimal faculty participation as research reviewers; extent of faculty participation in research activities was lower than the expectations of the university and the mandates of CHED. In addition, there are many faculty members with MAs and $\mathrm{PhDs}$ but their research productivity is low and the quantity and quality of research outputs need improvement (http://www.su.edu.ph/suakcrem/ched/ched html).

Abon, et.al (2003) reported that $92.95 \%$ of faculty nationwide have undertaken research and development activities for more than 20 years, but only $22.81 \%$ was involved in research in spite of incentives in the form of publication of research outputs, attendance in local/national/international conferences, honoraria, and research load credits. Also, Walls study (2006) showed that the most important barriers to investigators who initiated social science 
researches were the following (in their rank order): first, lack of time, the nature of academic work, and lack of funding; second, overhead levels within institutions, research funders" policies or practices, and problems with "buying out" teaching time for research; third, lack of internationally refereed publications, lack of recognition. However, Enriquez (2013) pointed out that despite the capability building activities, many faculty still had little confidence to do research. The administrator respondents were in agreement that faculty should be mentored by those with experience conducting empirical research.

Likewise, Colico (2016) revealed in her study that the private HEIs in Southern Leyte, generally are poor in the level of performance in research and fair in extension services. This was supported by Bernadit (2016) in her study findings and recommendations: the level of performance of faculty in research and extension was satisfactory which could be deduced as moderate competence, there is a need for them to enhance it through attendance in training or constantly involving themselves in research and extension; administration should provide financial support to motivate them to increase their productivity in research and extension; provide regular training, seminar, and workshop to all and extension implementers; active participation and involvement of faculty in research and extension so that their level of performance in these areas would be higher; faculty members should be de-loaded to acquire ample time for research and extension; regular assessment of the capabilities in research and extension must be conducted to enhance their appreciation and motivation in conducting research and extension.

Furthermore, the aforementioned citations of authorities focused on research and extension services. It has been found out that majority of the institutions were weak in these areas. Thus, this review served as inputs to this recent study.

\section{Materials and Methods}

This study employed a descriptive research design which describes systematically the facts and characteristics of a given population or area of interest, factually and accurately (Navarro and Santos 2011). Purposive sampling was employed for the 131 faculty respondents of the University but only 94 responded because some were on study leave and others were on official travel when the study was conducted.

The survey questionnaire used was adapted from the study of Bernadit (2016) with minor modifications. It has six parts namely: Part I- Personal Information; Part II-Level of Participation of Faculty in Research and Extension; Part III-Level of Performance of Faculty in Research and Extension; Part IV-Level of Motivations; Part V - Problems Encountered by Faculty in conducting Research and Extension; and Part VI -Suggested Solutions to the Problems encountered in Research and Extension.

The frequency count, percentage, mean and standard deviation were used in the statistical treatment of data.

\section{Results and Discussion}

1) The first question sought to assess the profile of LNU faculty in terms of: 
- Sex

Table 1: Sex of Faculty

\begin{tabular}{|l|l|l|}
\hline Sex & f & \% \\
\hline Male & 51 & 53 \\
\hline Female & 45 & 47 \\
\hline Total & 96 & 100 \\
\hline
\end{tabular}

As reflected in the above table, 51 or $53 \%$ of the respondents were males while 45 or $47 \%$ were reported as females.

\section{- Civil Status}

Table 2: Civil Status of Faculty

\begin{tabular}{|l|l|l|}
\hline Civil Status & f & $\mathbf{\%}$ \\
\hline Single & 23 & 24 \\
\hline Married & 63 & 65 \\
\hline Widow/Widower & 7 & 7 \\
\hline Separated & 2 & 2 \\
\hline Others & 2 & 2 \\
\hline Total & 97 & 100 \\
\hline
\end{tabular}

The table above shows that married status comprised the largest percentage of the respondents, which is 63 or $65 \%$ while 2 or $2 \%$ were separated and others status comprised the least proportion.

- Highest Educational Attainment

Table 3: Highest Educational Attainment of Faculty

\begin{tabular}{|l|l|l|}
\hline Highest Educational Attainment & $\boldsymbol{f}$ & $\boldsymbol{\%}$ \\
\hline Bachelor's Degree & 2 & 2 \\
\hline Master's Units & 10 & 11 \\
\hline Master's Degree & 24 & 25 \\
\hline Doctorate Units & 35 & 37 \\
\hline Doctorate Degree & 24 & 25 \\
\hline Total & 95 & 100 \\
\hline
\end{tabular}

The table above shows that most of the respondents have doctorate units, which comprised 35 or $37 \%$ of the group. Master's and doctorate degree respondents got 24 or $25 \%$. While bachelor's degree respondents have the lowest proportion that is 2 or $2 \%$ only. 
- Academic Rank

Table 4: Academic Rank of Faculty

\begin{tabular}{|l|l|l|}
\hline Academic Rank & f & \% \\
\hline Instructor 1 & 30 & 32 \\
\hline Instructor 2 & 1 & 1 \\
\hline Instructor 3 & 3 & 3 \\
\hline Assistant Professor 1 & 15 & 16 \\
\hline Assistant Professor 2 & 9 & 10 \\
\hline Assistant Professor 3 & 4 & 4 \\
\hline Assistant Professor 4 & 3 & 3 \\
\hline Associate Professor 1 & 5 & 5 \\
\hline Associate Professor 2 & 5 & 5 \\
\hline Associate Professor 3 & 8 & 9 \\
\hline Associate Professor 4 & 4 & 4 \\
\hline Associate Professor 5 & 4 & 4 \\
\hline Professor 1 & 1 & 1 \\
\hline Professor 5 & 1 & 1 \\
\hline Total & 93 & 100 \\
\hline
\end{tabular}

The table above shows that most of the respondents were instructor 1 that comprised 30 or $32 \%$. Likewise, assistant professor 1 respondents got 15 or $16 \%$ of the total. Professor 1 and 5 comprised the smallest proportion that is both 1 and $1 \%$ of the respondents.

- Length of Academic Experience

Table 5: Length of Experience of Faculty

\begin{tabular}{|l|l|l|}
\hline Length of Experience & $\boldsymbol{f}$ & $\%$ \\
\hline 1 year to 10 years & 30 & 41 \\
\hline 11 years to 15 years & 10 & 14 \\
\hline 16 years to 20 years & 17 & 23 \\
\hline 21 years to 25 years & 5 & 7 \\
\hline Above 25 years & 12 & 16 \\
\hline Total & 74 & 100 \\
\hline
\end{tabular}

The table above shows that the respondents got 1 year to 10 years academic experience that comprised 30 or $41 \%$ of the respondents. The next largest proportion of the respondents belongs to 16 years to 20 years academic experience. There were very few respondents who got 21 years to 25 years of experience, which is only 5 or $7 \%$ of the total respondents. 
- Academic / Administrative Designation

Table 6: Academic/Administrative Designation of Faculty

\begin{tabular}{|l|l|l|}
\hline Administrative/Academic Designation & f & $\%$ \\
\hline Alumni Director & 2 & 5 \\
\hline Student Teaching Supervisor & 1 & 3 \\
\hline Director & 4 & 10 \\
\hline Unit Chair & 13 & 33 \\
\hline Director_2 & 3 & 8 \\
\hline Coordinator & 6 & 15 \\
\hline Dean & 3 & 8 \\
\hline Vice President & 2 & 5 \\
\hline Testing Officer & 1 & 3 \\
\hline Night LNU House Manager & 1 & 3 \\
\hline Curriculum Manager & 1 & 3 \\
\hline Web Administrator & 1 & 3 \\
\hline BAC Technical Working Group & 1 & 3 \\
\hline Executive Assistant to the President & 1 & 3 \\
\hline Total & 40 & 100 \\
\hline
\end{tabular}

The table above shows that among respondents who gave their information on administrative / academic designation, unit chairs got the highest proportion that is 13 or $33 \%$. On the other hand, Student Teaching supervisor, testing officer, Night LNU House Manager, Curriculum Manager, Web administrator, BAC, Technical Working Group and Executive Assistant to the President comprised the least proportion with only 1 or $3 \%$ for each administrative / academic designation.

- Length of Academic / Administrative Designation

Table 7: Length of Academic/Administrative Designation of Faculty

\begin{tabular}{|l|l|l|}
\hline Length of Admin/ Academic Designation & f & \% \\
\hline 1 year to 5 years & 20 & 61 \\
\hline 6 years to 10 years & 4 & 12 \\
\hline 11 years to 15 years & 4 & 12 \\
\hline 16 years to 20 years & 2 & 6 \\
\hline 21 years to 25 years & 1 & 3 \\
\hline Above 26 years & 2 & 6 \\
\hline Total & 33 & 100 \\
\hline
\end{tabular}

The table above shows that the 20 or $61 \%$ of the respondents has length of service from 1 year to 5 years. In addition, only 1 or $3 \%$ of the faculty members had 21 years to 25 years in administrative / academic service. 
Number of Trainings /Seminars / Conferences attended related to research for the last three years.

Table 8: Faculty Research Trainings/Seminars/Conferences

\begin{tabular}{|l|l|l|}
\hline International & $\mathbf{f}$ & $\%$ \\
\hline 1 to 5 & 49 & 94 \\
\hline 6 to 10 & 2 & 4 \\
\hline 11 to 15 & 0 & 0 \\
\hline Above 16 & 1 & 2 \\
\hline Total & 52 & 100 \\
\hline
\end{tabular}

\begin{tabular}{|l|l|l|}
\hline National & f & \% \\
\hline 1 to 5 & 39 & 93 \\
\hline 6 to 10 & 1 & 2 \\
\hline 11 to 15 & 1 & 2 \\
\hline Above 16 & 1 & 2 \\
\hline Total & 42 & 100 \\
\hline
\end{tabular}

\begin{tabular}{|l|l|l|}
\hline Local & f & \% \\
\hline 1 to 5 & 56 & 86 \\
\hline 6 to 10 & 9 & 14 \\
\hline 11 to 15 & 0 & 0 \\
\hline Above 16 & 0 & 0 \\
\hline Total & 65 & 100 \\
\hline
\end{tabular}

The table above shows that respondents attended most in local research trainings/seminars/conferences for the last 3 years with a number of $56(86 \%)$ followed by international with a total of $49(94 \%)$ and the least was national with a total of $39(93 \%)$ only.

Number of trainings / seminars / conferences related to extension for the last three years.

Table 9: Faculty Extension Trainings/Seminars/Conferences

\begin{tabular}{|l|l|l|}
\hline International & $\mathbf{f}$ & $\boldsymbol{\%}$ \\
\hline 1 & 3 & 75 \\
\hline 2 & 1 & 25 \\
\hline Total & 4 & 100 \\
\hline
\end{tabular}

\begin{tabular}{|l|l|l|}
\hline National & $\mathbf{f}$ & $\boldsymbol{\%}$ \\
\hline 1 & 4 & 40 \\
\hline 2 & 1 & 10 \\
\hline 3 & 2 & 20 \\
\hline
\end{tabular}




\begin{tabular}{|l|l|l|}
\hline 4 & 1 & 10 \\
\hline 5 & 2 & 20 \\
\hline Total & 10 & 100 \\
\hline
\end{tabular}

\begin{tabular}{|l|l|l|}
\hline Local & f & \% \\
\hline 1 to 5 & 51 & 93 \\
\hline 6 to 10 & 4 & 7 \\
\hline Total & 55 & 100 \\
\hline
\end{tabular}

It can be seen from the table above that respondents attended most in local extension trainings/seminars/conferences for the last 3 years with a total number of 51 (93\%), followed by national with a total number of $4(40 \%)$ and the least was international with a total of $3(75 \%)$ only.

- Average Teaching Load

Table 10: Average Teaching Load of Faculty

\begin{tabular}{|l|l|l|}
\hline Average Teaching Load & f & \% \\
\hline 1 to 18 & 44 & 55 \\
\hline 19 to 30 & 31 & 39 \\
\hline Above 31 & 5 & 6 \\
\hline Total & 80 & 100 \\
\hline
\end{tabular}

It can be gleaned from the table above that 44 (55\%) respondents have 1 to 18 units teaching loads, $31(39 \%)$ have 19 to 30 units and $5(6 \%)$ have above 31 units of teaching loads.

- Number of Preparation

Table 11: Teaching Preparation of Faculty

\begin{tabular}{|l|l|l|}
\hline Number of Preparation & $\boldsymbol{f}$ & $\%$ \\
\hline Below 3 & 51 & 58 \\
\hline 4 to 6 & 34 & 39 \\
\hline 7 and above & 3 & 3 \\
\hline Total & 80 & 100 \\
\hline
\end{tabular}

The table above shows that $51(58 \%)$ of the respondents have below 3 preparations, $34(39 \%)$ have 4 to 6 preparations, and $3(3 \%)$ have 7 and above preparation for classroom teaching activities. 
- Number of Research Conducted

Table 12: Faculty Researches Conducted

\begin{tabular}{|l|l|l|}
\hline Number of Research Conducted & $\boldsymbol{f}$ & $\%$ \\
\hline Below 3 & 55 & 85 \\
\hline 4 to 6 & 8 & 12 \\
\hline 7 and above & 2 & 3 \\
\hline Total & 65 & 100 \\
\hline
\end{tabular}

It can be seen in the table above that $55(85 \%)$ of the respondents have below 3 researches conducted, $8(12 \%)$ have 4 to 6 researches conducted and $2(3 \%)$ have 7 and above researches conducted.

The second question sought to assess the level of participation of faculty in research and extension.

Table 13: Faculty Research and Extension Participation

\begin{tabular}{|l|l|l|l|}
\hline & N & Mean & Standard Deviation \\
\hline Level of Participation & 93 & 2.94 & 0.89 \\
\hline
\end{tabular}

The respondents got 2.94 mean rating that belongs to satisfactory performance. Level of participation in research and extension of the respondents slightly vary from the mean with a standard deviation of 0.89 . This result corroborate the findings of Colico (2016) and Bernadit (2016).

The third question sought to assess the level of performance of faculty in research and extension.

Table 14: Faculty Research and Extension Performance

\begin{tabular}{|l|l|l|l|}
\hline & N & Mean & Standard Deviation \\
\hline Level of Performance & 93 & 2.94 & 0.89 \\
\hline
\end{tabular}

The respondents got 2.94 mean rating that belongs to satisfactory performance. Level of participation in research and extension of the respondents slightly vary from the mean with a standard deviation of 0.89. This result is similar to the findings of Bernadit (2016).

The fourth question sought to assess the level of motivation of faculty in research and extension.

Table 15: Faculty Research and Extension Motivation

\begin{tabular}{|l|l|l|l|}
\hline Level of Motivation & $\boldsymbol{N}$ & Mean & Standard Deviation \\
\hline Intrinsic & 96 & 3.58 & 0.84 \\
\hline Extrinsic & 96 & 3.80 & 0.85 \\
\hline
\end{tabular}

The table above shows that the respondents got 3.58 and 3.80 mean rating on intrinsic and extrinsic motivation, respectively. This implies that respondents agree on the statements included for level of motivation. Level of motivation in research and extension of the respondents slightly vary from 
the mean with a standard deviation of 0.84 and 0.85 , respectively. This result is slightly similar to that of Bernadit (2016).

The fifth question sought to find out the problems encountered by faculty in the conduct of research and extension.

Table 16: Problems Encountered

\begin{tabular}{|c|c|c|}
\hline $\begin{array}{l}\text { No. of } \\
\text { Respondents }\end{array}$ & Problem & \\
\hline 51 & $\mathrm{P} 3$ & $\begin{array}{l}\text { Lack of time in conducting research and extension programs, } \\
\text { project, and activities }\end{array}$ \\
\hline 22 & P11 & $\begin{array}{l}\text { The purchase of the equipment and supplies necessary in extension } \\
\text { and research activities programs, project use were not given priority }\end{array}$ \\
\hline 21 & P8 & Lack of qualified staff to handle each area of concern \\
\hline 17 & $\mathrm{P} 10$ & $\begin{array}{l}\text { Lack of funds to implement the different programs, project, and } \\
\text { activities }\end{array}$ \\
\hline 15 & P6 & $\begin{array}{l}\text { Lack of incentives to personnel handling the different programs, } \\
\text { project, and activities }\end{array}$ \\
\hline 13 & $\mathrm{P} 4$ & $\begin{array}{l}\text { Lack of information dissemination to the community regarding the } \\
\text { college/ university programs, project, and activities }\end{array}$ \\
\hline 13 & $\mathrm{P} 14$ & $\begin{array}{l}\text { No recognitions from the community of the project, programs and } \\
\text { extended activities by the faculty members of the college/ university }\end{array}$ \\
\hline 13 & $\mathrm{P} 15$ & $\begin{array}{l}\text { No cooperation by the community on the project and other socio- } \\
\text { civic activities implemented by the faculty members }\end{array}$ \\
\hline 12 & P7 & $\begin{array}{l}\text { Lack of coordination among the personnel implementing the } \\
\text { different programs, project, and activities }\end{array}$ \\
\hline 11 & P9 & $\begin{array}{l}\text { Lack of consistency between the professed goals and the educational } \\
\text { needs of the community }\end{array}$ \\
\hline 11 & $\mathrm{P} 13$ & $\begin{array}{l}\text { Misallocation of funds to immediate use of items purchased and } \\
\text { critical supplies requirement not provided for. }\end{array}$ \\
\hline 10 & P5 & $\begin{array}{l}\text { Lack of coordination between the community and the college/ } \\
\text { university }\end{array}$ \\
\hline 10 & $\mathrm{P} 12$ & Unfair allocation of travel funds to existing positions or personnel \\
\hline 7 & $\mathrm{P} 1$ & $\begin{array}{l}\text { Have negative attitude in conducting research and extension } \\
\text { programs, project, and activities }\end{array}$ \\
\hline 5 & $\mathrm{P} 2$ & $\begin{array}{l}\text { Lack of knowhow and capability in conducting research and } \\
\text { extension programs, project, and activities }\end{array}$ \\
\hline
\end{tabular}

The table shows that problem number three (lack of time in conducting research and extension program, projects and activities) came out the highest with a total number of 51 respondents while problem number two (lack of knowhow and capability in conducting research and extension programs, projects and activities) was the lowest with a total number of 5 respondents. This result is quite similar with the findings of Bernadit (2016) for the three groups of respondents but one 
group identified problem number 8. Also, with the findings of Enriquez (2013) which is heavy academic workload hinders the conduct of research of the faculty members.

The sixth question sought to find out the solutions suggested by faculty on the problems encountered in the conduct of research and extension.

Table 17: Suggested Solutions

\begin{tabular}{|c|c|c|}
\hline $\begin{array}{l}\text { No. of } \\
\text { Respondents }\end{array}$ & Problem & \\
\hline 78 & S3 & $\begin{array}{l}\text { Proper time in conducting research and extension programs, project, } \\
\text { and activities }\end{array}$ \\
\hline 77 & $\mathrm{~S} 15$ & $\begin{array}{l}\text { Motivate through incentives, recognition, praise for their work/effort } \\
\text { extended to the college/ university }\end{array}$ \\
\hline 75 & S5 & $\begin{array}{l}\text { Provide proper information dissemination to the community regarding } \\
\text { the college/ university programs, project, and activities }\end{array}$ \\
\hline 75 & S16 & Explain the importance of the projects and activities extended to them \\
\hline 75 & S17 & Show them a good example, be an "idol"/ model individual to them \\
\hline 74 & $\mathrm{~S} 2$ & $\begin{array}{l}\text { Provide regular training, seminar and workshop to all research and } \\
\text { extension implementers' in their college/ university to obtain adequate } \\
\text { know-how about research and extension implementation }\end{array}$ \\
\hline 72 & S1 & $\begin{array}{l}\text { De-load the faculty who have handled research and extension } \\
\text { programs, project, and activities from their regular teaching hours for } \\
\text { them to have ample in their research and extension implementation }\end{array}$ \\
\hline 72 & S4 & Show them a good example, be an "idol"/ model individual to them \\
\hline 72 & S9 & Hire personnel duly qualified to handle each area of concern \\
\hline 72 & S11 & $\begin{array}{l}\text { Adequate funds to implement the different programs, project, and } \\
\text { activities }\end{array}$ \\
\hline 71 & S6 & $\begin{array}{l}\text { Provide adequate coordination between the community and the } \\
\text { college/ university }\end{array}$ \\
\hline 70 & S7 & $\begin{array}{l}\text { Provide incentives to personnel handling the different programs, } \\
\text { project, and activities }\end{array}$ \\
\hline 70 & S8 & $\begin{array}{l}\text { Provide proper coordination among the personnel implementing the } \\
\text { different programs, project, and activities }\end{array}$ \\
\hline 70 & S10 & $\begin{array}{l}\text { Develop consistency between the professed goals and the educational } \\
\text { needs of the community }\end{array}$ \\
\hline 70 & S14 & $\begin{array}{l}\text { Allocation of funds to its proper use purchased items as needed and } \\
\text { provides supplies }\end{array}$ \\
\hline 68 & S13 & Fairness allocation of travel funds to existing positions or personnel \\
\hline 66 & $\mathrm{~S} 12$ & $\begin{array}{l}\text { Prioritized in the purchase of equipment and supplies necessary in } \\
\text { extension and research activities, programs and projects of faculty } \\
\text { implementers }\end{array}$ \\
\hline
\end{tabular}


The above table shows that all the respondents were strongly agree on the suggested solutions to the problems encountered in conducting research and extension. However, suggested solution number 3 (proper time in conducting research and extension programs, projects, and activities) came out the highest with a total number of 78 respondents while suggested solution number 12 (prioritized in the purchase of equipment and supplies necessary in research and extension programs, projects and activities of faculty implementers) was the lowest with a total number of 66 respondents. This result differs the findings of Bernadit (2016), the four groups of respondents identified solutions number $7,8,2 \& 1$, respectively.

\section{Conclusions and Recommendations}

Based on the findings of this study, the following conclusions were drawn:

1) Majority of the respondents were males, married, have doctorate units, instructor 1, 1 to 10 years of academic experience, unit chairs with 1 to 5 years of experience, attended local research and extension trainings/seminars/conferences for the last 3 years, 1 to 18 units teaching loads, 3 and below teaching preparations, and 3 and below researches conducted.

2) Majority of the respondents got only satisfactory level of participation and performance in research and extension while most of them agree on the statements of intrinsic and extrinsic motivations. The Level of motivation of the respondents in research and extension slightly vary.

3) Lack of time came out the number one problem encountered by the respondents in conducting research and extension programs, projects and activities.

4) Proper time in conducting research and extension programs, projects, and activities was the highest number among the suggested solutions.

Based on the conclusions drawn from the findings of this study, the following recommendations are the recommendations:

1) In as much as the levels of participation and performance of faculty in research was found satisfactory which could be deduced as moderate competence, there is a need for them to continuously enhance it through attendance in training or constantly involving themselves in research and extension.

2) Active participation of faculty in research and extension so that their level of performance in these areas would be higher. Faculty members should be de-loaded for another 6 units per semester to acquire ample time for research and extension.

3) Regular assessment of the capabilities in research and extension must be conducted to enhance their appreciation and motivation in conducting research and extension.

4) Administrators must come up with proper scheduling of research and extension programs, projects and activities, classroom instructions and extra-curricular activities to avoid conflict in the conduct of these functions /activities.

5) Administrators shall provide opportunities to enable faculty to perform research and extension on equal footing with instruction.

6) The college deans in the institution being at the forefront of the different curricular programs are deemed potential catalyst in making research and extension a reality.

7) Another study may be conducted considering other areas in research and extension. 


\section{Proposed Policy to Improve the Levels of Participation, Performance and Motivation in Research and Extension}

Conduct capability building program through provision of regular training, seminar and workshop to all faculty researchers and extensionists to capacitate them in conducting research and extension. The administration should provide not only intrinsic motivators but also extrinsic motivators to faculty researchers and extensionists Proper scheduling, coordination and cooperation in the conduct of research, extension, instruction and other extra-curricular activities of the university. De-loading of faculty who are conducting research and implementing extension program/project from their regular teaching hours for them to have ample time in conducting their research and extension.

\section{Acknowledgements}

The author expressed his gratitude to the administrators, faculty and staff of Leyte Normal University, particularly to Dr. Jude A. Duarte, the university president, who approved the conduct of this study.

To all the faculty members of the university who answered the survey questionnaires and gave their time and effort. To Christian Abalos, for the statistical analysis of data and Christy, my secretary for always ready to help in encoding the data.

Finally, to the Lord God Almighty for without Him I can do nothing. Thank you.

\section{References}

[1] Braskamp, L.A. (2004). Assessing Faculty Work: Enhancing Individual and Institutional Performance. San Francisco, CA: Josey-Bass.

[2] Boyer, R.J. (2010). Changes in Academic Research Performance Over Time: A Study of Institutional Accumulated Advantage. Research in Higher Education.

[3] Daft, Stacy Adams. (2009). Management. $5^{\text {th }}$ Edition. New York: Academic Press

[4] Dayola-Colico, Marietta O. (2016). Level of Performance in Research and Extension Services of Provate Higher Education Institutions in Southern Leyte: Inputs to a Proposed Five-Year Research and Extension Development Plan. Ed.D. Dissertation. Leyte Normal University, Tacloban City, Philippines.

[5] Enriquez, Rutchellle B. (2013). Towards Shifting Paradigms: Repositioning LNU Through Research, Innovation and Creative Works: An Action Plan and Project._Leyte Normal University, Tacloban City, Philippines.

[6] Lawler, P. (2004). The Academic Profession in International Perspective. Princeton, NJ Carneige Foundation for the Advancement of Learning.

[7] LNU Research Manual and Implementing Guidelines, RDO, 2011

[8] LNU Community Extension Services Manual, Revised Edition, 2014

[9] Middaugh, M.F. (2010). Understanding Faculty Productivity: Standards and Benchmarks for Colleges and Universities. San Francisco, CA: Josey-Bass.

[10] Moore, F.E. \& Amey, L.A. (2003). Institutional Factors that Motivate Activity in the Research Universities. Paper Presented at the Annual Meeting of the Association for the Study of Higher Education, St.Louis, M.O.

[11] Revised Leyte Normal University Code (Approved per LNU BOR Res.No.765 dated October 11, 2015) 
[12] Sarzata-Bernadit, Leonida. (2016). The Level of Motivation and Performance in Research and Extension of faculty in State Colleges and Universities (SUCs) in Eastern Visayas: Bases for Policy Redirection. Ph.D. Dissertation. Samar State University, Catbalogan City, Samar, Philippines

[13] Villarino, Gil Nicetas B. (2015). Research Capability of State Universities and Colleges

[14] (SUCs) in Region 8. Ph.D. Dissertation. Eastern Visayas State University, Tacloban City, Philippines

*Corresponding author.

E-mail address: nestorsedanza61@ yahoo.com.ph 